\title{
Observation for spoilage in fish and beef in a daily simulated local market style of Southwestern, Nigeria.
}

\author{
Ilori, Opeyemi Damilare ${ }^{1}$, Adekolurejo, Opeyemi Oyinda², and Awoniyi, \\ Tunde $\mathrm{Amos}^{2}$ Mcjones
}

Department of Animal Production and Health, Federal University of Technology, Akure Ondo State, Nigeria.

E-Mail: Opeyemisam4real@yahoo.com, +2348060687651

Opeyemi.adekolurejo@gmail.com, +2348057189080

\begin{abstract}
The degree of spoilage of fish and beef in a daily simulated market style of southwest, Nigeria was determined by Trimethylamine (TMA) levels in each sample using the standard pictrate technique. $100 \mathrm{~g}$ of each of the three different parts of a bull (liver, meaty and fatty tissues) and fresh African cat fish (Clarias gariepinus) (liver, meaty portion and head) were purchased twice a week for five weeks from the abattoir and Oja-Oba market in Akure respectively. The samples were subjected to ambient temperature and their degree of spoilage was assessed after 3 hours, 6 hours and 9 hours of purchase. The results showed that, there was no significant difference ( $P \geq 0.05$ ) in the effect of time (hours) on TMA concentration in different parts of the fish and bull samples, though, the mean concentration of TMA in the fish samples increased with time. However, the degree of spoilage is slower in the bull compared to the fish samples but higher in the late evening (9 hours). Hence, buying and selling of beef in the late evening should be discouraged to avoid consumption of unwholesome meat with high TMA concentrations, while fish should be stored-frozen and sold in deep freezers.
\end{abstract}
Keywords: Beef spoilage, Fish spoilage,

Trimethylamine (TMA).

\section{INTRODUCTION}

Fish and meats are important components of human diet. Their nutritive value and palatability are widely appreciated. Despite the relevance of fish and meat in human diet as well as in the economy of Nigeria, a large quantity of fish and beef are prone to spoilage which could be as a result of activity of pathogenic bacteria and fungi thus, making fish or meat unfit for human consumption. Spoilage of fish and beef is a problem for livestock producers, retailers and consumers; it could result to food wastage and consequently economic losses leading to reduction in the profit made by farmers. The practice of freezing and selling of spoilt fish and beef is a great public health hazard. As a result, there is a considerable universal interest in spoilage rate of tropical fish and meat from animals in response to ambient temperature in order to curtail the rising incidence of diseases resulting from food borne sources. Fish bacteria are very sensitive to temperature and the rate at which bacteria multiply depends upon environmental temperature and this leads to spoilage (Doyle, 2007, Nuin et al., 2008). Trimethylamine (TMA), (CH3) $3 \mathrm{~N}$ is a tertiary amine which is gaseous at normal temperature and has a characteristic smell of rotting fish. Trimethylamine content is an indicator of meat/fish quality, and picric acid reaction to form an intensely yellow coloured pi-complex and is a standard method for its determination (Francisco et al., 2010). The TMA content determines the flavor of meat and it is also an important factor which determines the natural quality of meat (Mohammod et al., 2013). Trimethylamine (TMA) levels are used universally to determine microbial deterioration leading to spoilage of both fish and meat. The amount of TMA produced is a measure of the activity of spoilage bacteria in the flesh, thus it is an indicator of spoilage (Dalgaard et al., 2006).

Unfortunately, there is notable dearth of information in terms of previous studies describing or comparing the degree of spoilage of fish and beef sold at various markets in the south west Nigeria, at different hours of the day in response to ambient temperature. Hence, this study was conducted to; determine and compare the degree of spoilage of fish and beef in response to time and ambient temperature by chemical analysis of Trimethylamine (TMA) levels in fish and beef samples measured using the 
standard picrate technique described by Muray and Gibson, (1972a and b) and to ascertains the wholesomeness of fish and beef offered for sale at different hours of the day at OjaOba market in Akure, Southwestern, Nigeria.

\section{MATERIALS AND METHODS}

\section{Study Area}

This experiment was carried out in the nutrition laboratory of the Department of Animal Production and Health, Federal University of Technology, Akure, Ondo state, Nigeria

\section{Collection of samples}

Three samples each of different part of a bull (liver, meaty and fatty portion) and fresh African cat fish (Clarias gariepinus) (liver, meaty portion and head) were purchased twice a week for five weeks from abattoir and Oja-Oba market in Akure respectively and transported to the laboratory. The baseline temperature of the samples were recorded immediately after purchased with a resistance thermometer probe and tagged as the control. The samples were then subjected to ambient temperature and their degree of spoilage was evaluated after 3 hours, 6 hours and 9 hours of purchase. Spoilage was assessed by chemical analysis of the level of Trimethylamine (TMA) in each of the purchased samples were measured using the standard pictrate technique described by Muray and Gibson, (1972a and b).

\section{Statistical analysis}

Data obtained was analyzed (SAS version 9.1) using a factorial analysis to test the significant difference in the mean values of TMA concentration and ambient temperature of fresh fish and beef samples at different stages of spoilage while separation of means was done using the Duncan's Multiple Range Test,

the difference in mean was considered significant at $\mathrm{P} \leq 0.05$.

\section{RESULTS}

Table 1 shows the mean values of TMA concentration ( $\mu \mathrm{g}$ TMA /100g ) of liver, meaty portion and head of catfish at different hours of the day. There was significant difference $(\mathrm{P} \leq 0.05)$ in the TMA concentration of the liver, meaty portion and head of catfish as the time (hours) increases from $0-9$ hours. However, there was no significant difference $(\mathrm{P} \geq 0.05)$ in the TMA concentration among the liver, meaty portion and head of catfish at 0 hours, 3 hours, 6 hours and 9 hours.
Table.1: Effect of time (hours) on TMA concentration $(\mu \mathrm{g} T M A / 100 \mathrm{~g})$ of different parts of fish (Mean \pm

$S D)$

\begin{tabular}{llll}
\hline $\begin{array}{l}\text { Time } \\
\text { (hours) }\end{array}$ & Liver & $\begin{array}{l}\text { Meaty } \\
\text { portion }\end{array}$ & Head \\
\hline 0 & $2.090 \pm 0.006^{\mathrm{d}}$ & $2.148 \pm 0.009^{\mathrm{d}}$ & $2.036 \pm$ \\
& & & $0.007^{\mathrm{d}}$ \\
3 & $3.665 \pm 0.040^{\mathrm{c}}$ & $3.591 \pm 0.051^{\mathrm{c}}$ & $3.770 \pm$ \\
& & & $0.067^{\mathrm{c}}$ \\
6 & $5.552 \pm 0.087^{\mathrm{b}}$ & $5.424 \pm 0.110^{\mathrm{b}}$ & 5.789 \\
& & & $\pm 0.055^{\mathrm{b}}$ \\
9 & $10.303 \pm 0.131^{\mathrm{a}}$ & $10.067 \pm 0.120^{\mathrm{a}}$ & 10.966 \\
& & & $\pm 0.218^{\mathrm{a}}$ \\
\hline
\end{tabular}

$(\mathrm{a}-\mathrm{d})=$ mean values on the same row with different superscript are significantly different $(\mathrm{p}<0.05) . \mathrm{SD}=$ Standard Deviation

Table 2 shows the mean values of TMA concentration $(\mu \mathrm{g}$ TMA $/ 100 \mathrm{~g})$ of liver, meaty and fatty tissues of bull at different hours of the day. There was significant difference $(\mathrm{P} \leq 0.05)$ in the TMA concentration of the liver, meaty and fatty tissues of the bull as the time (hours) increases from 0 -9 hours with fatty tis sues giving the higher mean values of TMA concentration ( $\mu$ TMA $/ 100 \mathrm{~g})$ at 3 hour $\left(3.389 \pm 0.014^{\mathrm{a}}\right), 6$ hour $\left(4.447 \pm 0.052^{\mathrm{a}}\right)$ and 9 hour $(8.237 \pm$ $\left.0.046^{\mathrm{a}}\right)$ respectively.

Table.2: Effect of time (hours) on TMA concentration $(\mu \mathrm{g}$ TMA $/ 100 \mathrm{~g})$ of different parts ofbull (Mean $\pm S D)$

\begin{tabular}{llll}
\hline $\begin{array}{l}\text { Time } \\
\text { (hours) }\end{array}$ & Liver & $\begin{array}{l}\text { Meaty } \\
\text { portion }\end{array}$ & Fatty tissue \\
\hline 0 & 1.948 & $1.894 \pm 0.007^{\mathrm{d}}$ & $1.795 \pm 0.013^{\mathrm{d}}$ \\
& $\pm 0.004^{\mathrm{d}}$ & & \\
3 & $3.243 \pm 0.008^{\mathrm{b}}$ & $3.161 \pm 0.012^{\mathrm{c}}$ & $3.389 \pm 0.014^{\mathrm{a}}$ \\
6 & $4.335 \pm 0.007^{\mathrm{b}}$ & $4.290 \pm 0.008^{\mathrm{c}}$ & $4.447 \pm 0.052^{\mathrm{a}}$ \\
9 & $7.767 \pm 0.048^{\mathrm{a}}$ & $7.173 \pm 0.118^{\mathrm{b}}$ & $8.237 \pm 0.046^{\mathrm{a}}$ \\
\hline
\end{tabular}

$(\mathrm{a}-\mathrm{d})=$ mean values on the same row with different superscript are significantly different $(\mathrm{p}<0.05) . \mathrm{SD}=$ Standard Deviation

Table 3 shows the mean values of ambient temperature $\left({ }^{0} \mathrm{C}\right)$ of liver, meaty portion and head of catfish at different hours of the day. At 0 hour, the analysis of variance shows that the ambient temperature of liver, meaty portion and head of catfish different significantly $(\mathrm{P} \leq 0.05)$ from the ambient temperature of the liver, meaty portion and head of catfish at 3 hours, 6 hours, 9 hours. However, there was no significant different $(\mathrm{P} \geq 0.05)$ in the ambient temperature among the liver, meaty portion and head of catfish at 3 hours, 6 hours and 9 hours. 


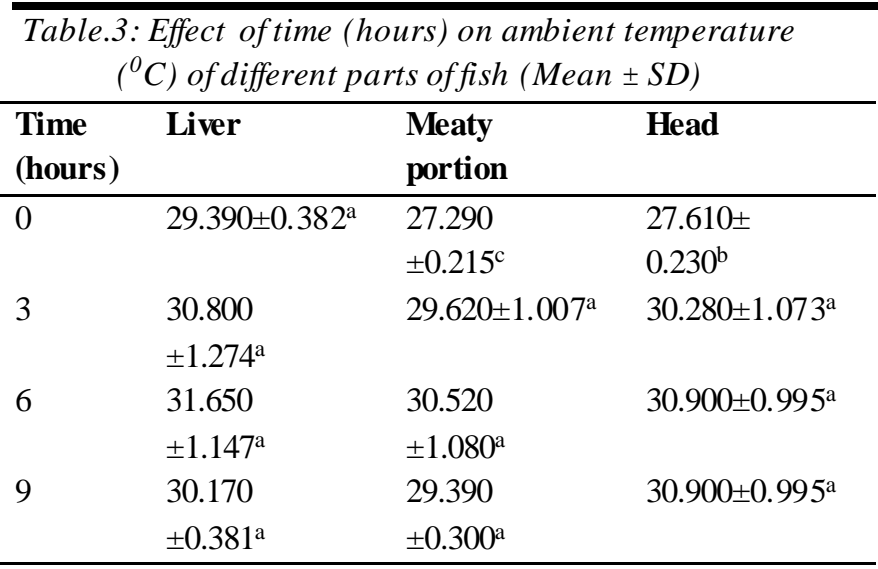

$(a-b)=$ mean values on the same row with different superscript are significantly different $(\mathrm{p}<0.05)$. $\mathrm{SD}=$ Standard Deviation

Table 4 shows the mean values of ambient temperature $\left({ }^{0} \mathrm{C}\right)$ of liver, meaty and fatty portion of the bull at different hours of the day. The analysis of variance shows that there was significant difference $(\mathrm{P} \leq 0.05)$ in ambient temperature of the liver, meaty and fatty tissues of the bull as the time (hours) increases from $0-9$ hours with fatty tissues giving the higher mean values of ambient temperature at 3 hour $\left(34.320 \pm 1.361^{\mathrm{a}}\right), 6$ hour $\left(36.280 \pm 1.222^{\mathrm{a}}\right)$ and 9 hour $\left(32.691 \pm 0.489^{\mathrm{a}}\right)$ res pectively.

Table.4: Effect of time (hours) on ambient temperature $\left({ }^{0} \mathrm{C}\right)$ of different parts of bull (Mean $\left.\pm S D\right)$

Deviation

\begin{tabular}{llll}
\hline $\begin{array}{l}\text { Time } \\
\text { (hours } \\
\text { ) }\end{array}$ & Liver & $\begin{array}{l}\text { Meaty } \\
\text { portion }\end{array}$ & Fatty tissue \\
\hline 0 & $27.510 \pm$ & $28.830 \pm 0.239$ & $28.360 \pm 0.29$ \\
& $0.250^{\mathrm{b}}$ & $\mathrm{b}$ & $0^{\mathrm{b}}$ \\
3 & $32.230 \pm 1.072$ & $31.250 \pm 0.883$ & $34.320 \pm 1.361^{\mathrm{a}}$ \\
& $\mathrm{b}$ & $\mathrm{c}$ & \\
6 & $33.790 \pm 1.111$ & $32.400 \pm 0.808$ & $36.280 \pm 1.22$ \\
& $\mathrm{~b}$ & $\mathrm{c}$ & $2^{\mathrm{a}}$ \\
9 & $29.440 \pm 0.338$ & $\begin{array}{l}29.590 \pm 0.368 \\
\text { bc }\end{array}$ & $32.691 \pm 0.489^{\mathrm{a}}$ \\
& $\mathrm{bc}$ & $\mathrm{C}$ \\
\hline
\end{tabular}

$(\mathrm{a}-\mathrm{c})=$ mean values on the same row with different superscript are significantly different $(\mathrm{p}<0.05) . \mathrm{SD}=$ Standard Deviation

\section{DISCUSSION}

From the study, the TMA concentration of different parts of the fish and bull at different hours of the day were not significantly different $(\mathrm{P} \geq 0.05)$ from each other though, the mean value of TMA concentration of different parts of fish (liver, meaty portion and head) as well as different parts of

bull (liver, meaty and fatty portion) increased as the time (hours) increased. The mean values of TMA concentration in the head of the sacrificed fish was slightly lower at the start of the experiment than that of liver and meaty portion of the same fish, but the opposite was the case at the end of the experiment ( 9 hours after) where the TMA concentration was higher in the fish head than that of liver and meaty portion. This implies that rate of spoilage is faster in fish head compare to other parts such as liver and meaty portion. This could be as a result of myriad of spoilage microorganisms inhabiting the gills of the fish. The longer the period of exposure of fish or beef to ambient temperature, the higher the level of TMA in the sample, hence, the faster the rate of spoilage, this increase in TMA level in response to time and ambient temperature was also observed by Adeyemo et al., (2008).This study also revealed that the mean values of TMA concentration in the fatty tissues of the bull was slightly lower at the start of the experiment compared to liver and meaty portion of the same animal but at 3 hours, 6 hours, and 9 hours of the experiment, the mean values of TMA concentration of the fatty tis sues were slightly higher than other parts of the bull (liver and meaty portion), similar to observations by Zeev et al., (2002).This could be due to increase in ambient temperature at this hour of the day which enhanced the proliferation of microorganism and hence, the degree of spoilage. These findings indicated that the rate of spoilage is faster and higher in fatty tissues than other parts of the bull.

Comparatively, this study showed that the rate of spoilage is faster in fish liver both at the start and end of the experiment than that of bull. More so, the meaty portion of the fish spoils faster than that of the bull due to higher level of TMA in the meaty portion of fish both at the start and end of the experiment. The activities of microorganisms are largely responsible for spoilage of fish and meat leading to increase in the TMA level in the affected fish and meat (Adeyemo et al., 2008).

High ambient temperature enhances the multiplication of putrefactive organisms leading to spoilage. Spoilage bacteria respond to temperature and the extent at which bacteria proliferate depends largely on environmental temperatures which result into spoilage of fish and meat. The higher the ambient temperatures, the faster the spoilage rate of different parts of the fish and meat in the tropical environments. The assessment of rate of spoilage of different parts of fish by exposure to ambient temperature revealed no statistically significant difference at $(\mathrm{P} \geq 0.05)$ at 3hours, 6hours, and 9hours of the experiment. At zero hour, 
the analysis of variance shown that the ambient temperature $\left({ }^{0} \mathrm{C}\right)$ of fish liver, meaty portion as well as fish head different significantly at $(\mathrm{P} \leq 0.05)$ from exposure of aforementioned samples to ambient temperature $\left({ }^{0} \mathrm{C}\right)$ at 3 hours, 6 hours, 9 hours, this difference in ambient temperature could be attributed to vagaries nature of climate and weather. The assessment of rate of spoilage of different part of bull by exposure to different ambient temperatures at 3 hour, 6hour, and 9 hour showed that mean values of ambient temperatures of fatty tissues were significantly different at $(\mathrm{P} \leq 0.05)$ than other parts such as and meaty portion. This indicates that degree of spoilage is higher in fatty tissues than other parts of bull, as a result, fatty tissues spoil faster when compared with others due to increase in ambient temperature which corroborates the growth of putrefactive organis ms.

\section{CONCLUSION}

This experiment is relevant to this study environment because marketing of fish and beef is done under unmanipulated tropical temperature which enhances the growth of natural mesophilic microorganisms on tropical fish species and meat from animals. This observation of fish and beef in response to daily ambient temperature enables the understanding of the gradual spoilage of the fresh meat and fresh fish which in turn provide useful information for marketing and distribution of fish and meat in the tropical environment. Based on the results of this experiment, it can be concluded that the degree of spoilage is slower in beef compared to fish under the same condition such as period of exposure to different ambient temperature.

\section{RECOMMENDATIONS}

It is therefore recommended that buying and selling of meat in the late evening should be discouraged to reduce the risk of consumption of unwholesome meat by the public due to decay/putrefaction which increased TMA recorded in this study indicates. Consumers should endeavor to purchase meat within a short time after slaughtering process to prevent the consumption of unhygienic meat especially where storage facility is in doubt. Fish should be well frozen, stored and sold in deep freezers. Fishmongers and butchers should be enlightened via extension services on hygienic handling of fish and meat to avert multiplication of bacteria.

\section{REFERENCES}

[1] Adeyemo, O.K.., Aluko, O.O., Agbede, S.A. (2008). Effect of temperature on spoilage of fresh and frozen fish sold in markets in Ibadan, Nigeria. African Journal of Livestock Extension, 6: 65-68.

[2] Dalgaard, P., Madsen, H.L., Samieian, N. and Emborg, J. (2006). Biogenic amine formation and microbial spoilage in chilled garfish (Belone belone) effect of modified atmosphere packaging and previous frozen storage. Journal of Applied Microbiology, 101: 80-95.

[3] Murray, C.K. and Gibson D.M. (1972a). An investigation of the method of determining trimetylamine in fish muscle extracts by formation of its picrate salt. Part I. Journal of food Technology, 7: $35-46$

[4] Murray, C.K. and Gibson D.M. (1972b.) An investigation of the method of determining trimetylamine in fish muscle extracts by formation of its picrate salt. Part II. Journal offood Technology, 7: 47-51

[5] Nuin M, A. B., Cruz, Z., Argarate, N., George, S., Le Marc, Y., Olley, J., and Pin, C.(2008). Modelling spoilage of fresh turbot and evaluation of a timetemperature integrator (TTI) label under fluctuating temperature. International Journal of Food Microbiology 127(3): 193-199

[6] Doyle, E.M. (2007).Microbial food spoilage Losses and control strategies. Food Research Institute, University of Wisconsin Madison,WI 53706.

[7] Zeev, K., Boris, T., Rachel, G., and Avraham, L. (2002). Determination of volatile biogenic amines in muscle food products by ion mobility spectrometry. Analytica Chimica Acta 463:155-163. 